\title{
ANALISIS SIKAP DAN PERILAKU PETANI TERHADAP DUA BENIH JAGUNG HIBRIDA (JAYA DAN BISI 2) DI DESA SUKASARI KECAMATAN AIR PERIUKAN KABUPATEN SELUMA
}

\author{
THE ANALYSIS OF FARMERS ATTITUDE AND BEHAVIOR OF TWO HYBRID \\ CORN SEED (JAYA DAN BISI2) IN SUKASARI VILLAGE SUBDISTRICT OF AIR \\ PERIUKAN DISTRICT OF SELUMA
}

\author{
Rika Dwi Yulihartika \\ Program Studi Agribisnis, Fakultas Pertanian, UNIVED \\ Email : rikadwiyh13@gmail.com
}

\begin{abstract}
ABSTRAK
Benih sebagai sarana produksi pertanian merupakan suatu titik awal kegiatan budidaya, sehingga kualitas produk budidaya akan sangat bergantung pada kualitas benihnya. Strategi pemasaran benih yang efektif dan efisien dalam memenuhi kebutuhan dan kualifikasi petani bagi produsen benih akan sangat menentukan keberhasilan dan keunggulan pemasaran di masa mendatang. Karena itu tidak mengherankan jika produsen yang unggul adalah produsen yang paling berhasil memuaskan dan menyenangkan petani bahkan menciptakan petani sebagai pelanggan. Untuk itu, produsen memerlukan strategi pemasaran yang salah satunya dengan mengetahui bagaimana sikap dan perilaku petani terhadap benih jagung hibrida melalui pendekatan atribut-atribut.

Penelitian ini bertujuan untuk mengetahui: (1) sikap petani terhadap benih jagung hibrida merk Jaya dan merk Bisi 2, (2) Perilaku petani terhadap benih jagung hibrida merek Jaya dan merk Bisi 2, dan (3) Apakah terdapat perbedaan sikap petani terhadap benih jagung hibrida merk Jaya dan merk Bisi 2 sebagai benih jagung unggul dan mendominasi pasar saat ini. Responden dalam penelitian ditentukan dengan metode simple random sampling sebanyak 66 petani. Metode analisis yang digunakan adalah Metode Deskriptif, Analisis Sikap Fishbein dan Uji Beda komparatif dua mean dari dua sampel dengan Z-test.

Hasil penelitian menunjukkan bahwa : (1) Sikap Petani terhadap benih jagung merk Jaya dan merk Bisi 2 adalah biasa saja, (2) Perilaku petani terhadap benih jagung merk Jaya dan merk Bisi 2 adalah positif, dan (3) Sikap petani terhadap produk benih jagung merk Jaya dan merk Bisi 2 secara statistik adalah sama atau tidak berbeda nyata
\end{abstract}

Kata Kunci : sikap, perilaku, Jaya, Bisi 2

ABSTRACT

The Seed as agriculture substance represent a starting points which one of significant factor that determines quality and quantity agriculture yield. The efficient and effective of marketing strategy in fulfilling farmers requirement and qualified for producer will be determined of succesful and preeminently in the future. In consequence, there is not surprise that the preeminent producer is most successful producer for gratify and satisfy the farmer and than create farmer as a customer. Finally, producer need the marketing strategy which one of them is find out that how attitude and farmer behavior to corn hybrid seed through attribute approach 
This research is aimed to find out : (1) Farmers' attitude of corn hybrid seed of Jaya and corn hybrid seed of Bisi2, (2) Farmers' behavior of corn hybrid seed of Jaya and Bisi2, (3) Are there difference of farmer attitude to corn hybrid seed of Jaya and corn hybrid seed of Bisi2 as preminent corn hybrid seed and predominate the market in this time. Responder in research determined with the method of simple random sampling as much 66 farmers. Analysis method used by Descriptive Method, Attitude Analysis of Fishbein and Comparability Test of two mean from two sampel by Z-Test.

The result of research indicate that : (1) Farmer attitude toward to of corn hybrid seed of Jaya and corn hybrid seed of Bisi2 is neither positive or negative, (2) Farmer behavior toward to corn hybrid seed of Jaya and corn hybrid seed of Bisi2 is positive, and ( 3) Farmers attitude toward to product of corn hybrid seed of Jaya and product of corn hybrid seed of Bisi2 is equal or do not different by statistic.

Key Words : attitude, behavior, Jaya, Bisi2

\section{PENDAHULUAN}

Kemajuan dan pembangunan sektor pertanian tidak dapat terlepas dari kemajuan pembangunan sarana dan prasarana pertanian. Pembangunan sarana dan prasarana pertanian akan menopang sektor pertanian secara global ke arah pembangunan nasional berbasis agribisnis yang tangguh, dinamis dan berkeadilan. Hal-hal yang harus diperhatikan adalah pengadaan dan pelancaran sarana produksi, kebijaksanaan tataniaga dan harga, input dan output pertanian serta jalan dalam usahatani.

Salah satu sarana produksi pertanian adalah benih. Benih sebagai sarana produksi pertanian merupakan suatu titik awal kegiatan budidaya, sehingga kualitas produk budidaya akan sangat bergantung pada kualitas benihnya. Oleh karena itu, penyediaan benih bermutu di tingkat nasional, propinsi bahkan daerah perlu dikelola dengan baik agar kegiatan budidaya dapat menguntungkan pihak produsen maupun konsumen. Menurut Darmowiyono (1999), benih bermutu dari kompetitor unggul yang tersedia baik bagi petani maupun pengusaha agribisnis hendaknya memenuhi prinsip enam tepat yaitu : tepat jenis/kompetitor, tepat jumlah, tepat mutu, tepat lokasi, tepat waktu dan tepat harga. Untuk itu setiap industri benih perlu melakukan inovasi teknologi yang memiliki keunggulan kompetitif untuk menghasilkan kompetitor-kompetitor baru maupun hibrida-hibrida yang lebih unggul dan disetujui pasar.

Teknologi rekayasa genetik memungkinkan produsen benih untuk mengisolasi DNA dari berbagai organisme dan menggabungkannya ke dalam suatu organisme yang lain sehingga menghasilkan organisme dengan sifat yang berbeda. Teknik ini juga diterapkan dalam usaha menciptakan tanaman dengan 
sifat-sifat unggul, sehingga dapat meningkatkan hasil produksi pertanian pada umumnya. Rekombinasi DNA dianggap sebagai bentuk baru dari alam atau penemuan baru sehingga pada perkembangannya kemudian tanaman transgenik dapat dipatenkan. Tetapi di Indonesia berdasarkan UU No.14 tahun 2001 mengenai paten, makhluk hidup kecuali jasad renik tidak dapat dipatenkan, sehingga perlindungan bibit unggul diatur dalam UU No.29 tahun 2000 mengenai Perlindungan Merek Tanaman (PVT).

Salah satu tanaman pangan yang telah mendapatkan PVT di Indonesia adalah jagung. Jagung merupakan salah satu tanaman pangan terpenting selain beras dan kedelai. Sampai musim tanam 2004/2005 jumlah lahan yang ditanami jagung hibrida di Indonesia hanya mencapai $22 \%$, sangat jauh jika dibandingkan dengan Filipina dengan angka $65 \%$ atau Thailand dengan angka $98 \%$. Gambaran ini menjadi argumentasi untuk meningkatkan penggunaan benih jagung hibrida. Dewan Jagung Nasional yang beranggotakan wakil pemerintah dan industri, menargetkan peningkatan penggunaan jagung hibrida 10 persen tiap tahunnya (Anonim, 2007).

Kabupaten Seluma merupakan salah satu daerah sentra jagung di Propinsi Bengkulu.. Dari sebaran produksi jagung di Propinsi Bengkulu tahun 2014, Kabupaten Seluma merupakan daerah penyumbang terbesar setelah Kabupaten Rejang Lebong. Data perkembangan luasan panen, produksi serta produktivitas jagung di Kabupaten Seluma diperlihatkan oleh Tabel 1.

Tabel 1. Data perkembangan luasan panen, produksi serta produktivitas jagung di Kabupaten Seluma tahun 2009-2014

\begin{tabular}{cccc}
\hline Tahun & $\begin{array}{c}\text { Luasan panen } \\
(\mathrm{Ha})\end{array}$ & $\begin{array}{c}\text { Produksi } \\
(\text { ton })\end{array}$ & $\begin{array}{c}\text { Produktivitas } \\
(\mathrm{Kw} / \mathrm{Ha})\end{array}$ \\
\hline 2009 & 6.749 & 12.891 & 19,10 \\
2010 & 9.203 & 24.787 & 26,93 \\
2011 & 3.487 & 8.567 & 24,57 \\
2012 & 3.098 & 8.088 & 26,11 \\
2013 & 7.621 & 20.834 & 27,34 \\
2014 & 4.494 & 12.081 & $26,88^{*}$ \\
\hline
\end{tabular}


Saat ini, luas lahan yang ditanami benih jagung hibrida oleh petani di Kabupaten Seluma cukup tinggi dibanding rata-rata penggunaan jagung hibrida di Indonesia. Sampai musim tanam 2013/2014, jumlah lahan yang ditanami jagung hibrida di Kabupaten Seluma sebesar $58 \%(4.416 \mathrm{Ha})$ dan sisanya diisi oleh jagung komposit dan lokal. Dari lahan yang ditanami tersebut, kebutuhan benih jagung hibrida yang direkomendasi oleh Dinas Pertanian dan Ketahanan Pangan adalah sebesar 15 $\mathrm{kg} / \mathrm{Ha}$ dan jagung komposit sebesar 25 $30 \mathrm{~kg} / \mathrm{Ha}$.

Desa Sukasari merupakan salah satu daerah sentra produksi jagung di Kabupaten Seluma Propinsi Bengkulu. Dalam budidaya tanaman jagung, petani di daerah tersebut dihadapkan oleh berbagai merek benih jagung hibrida yang berjumlah tidak kurang dari dua puluh merek benih yang diterjumkan oleh produsen ke pasaran. Namun kenyataannya, sebagian bagian besar petani di daerah tersebut menggunakan benih jagung hibrida merk Jaya dan Bisi2. Kedua jenis merek jagung tersebut masing-masing memiliki kekuatan dan kelemahan sehingga dapat diterima oleh pasar dan mampu mendominasi pangsa pasar di Desa Sukasari khususnya dan Kabupaten Seluma pada umumnya. Setiap petani memiliki preferensi yang kuat untuk memilih salah satu merek jagung tersebut yang memiliki kekuatan atribut yang menonjol. Menurut Swasta dan Handoko (1987) jika seseorang konsumen mengambil keputusan untuk membeli maka ia akan menjumpai serangkaian keputusan yang harus diambil mengenai jenis produk, merk, penjual, kualitas, waktu pembelian dan pembayaran.

\section{METODOLOGI PENELITIAN}

\section{Metode Penentuan Lokasi}

Lokasi penelitian ditentukan secara sengaja (purposive), yaitu di Desa Sukasari Kecamatan Air Periukan Kabupaten Seluma. Daerah tersebut dijadikan lokasi penelitian dengan pertimbangan bahwa daerah ini merupakan sentra tanaman jagung di Kebupaten Seluma dan dalam budidayanya menggunakan benih jagung di mana benih jagung merek Jaya dan Bisi 2 adalah benih paling dominan digunakan petani.

\section{Metode Penentuan Responden}

Responden dalam penelitian ini adalah petani (konsumen) yang telah menggunakan benih jagung hibrida merek Jaya dan Bisi 2dengan kriteria :

1. Responden adalah petani yang telah menggunakan kedua jenis benih tersebut dua kali atau lebih. 


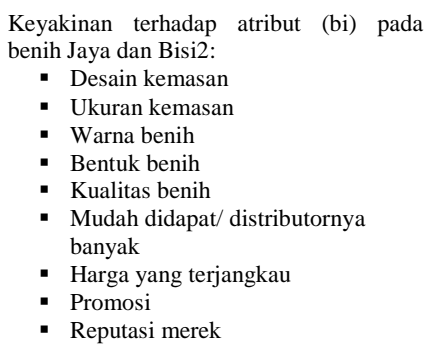

- Ukuran kemasan

- Warna benih

- Bentuk benih

- Kualitas benih

- Mudah didapat/ distributornya

banyak

- Harga yang terjangkau

- Promosi

- Reputasi merek

Evaluasi terhadap atribut (ci) pada benih Jaya dan Bisi2 :

- Desain kemasan

- Ukuran kemasan

- Warna benih

- Bentuk benih

- Kualitas benih

- Mudah didapat/ distributorny

banyak

- Harga yang terjangkau

- Promosi

- Reputasi merek

Keyakinan tentang perilaku (bi) terhadap pembelian benih Jaya dan Bisi2 :

- Potensi produksi yang relatif tinggi

- Daya adaptasi yang baik terhadap cuaca

- Harga tidak memberatkan secara keuangan bagi petani

- Memiliki perakaran dan batang yang baik dan kokoh

- Toleran terhadap penyakit bulai

- Memiliki umur panen relatif singkat

- Tanggap terhadap pemupukan

- Cocok untuk penanaman rapat / sela

Evaluasi tentang perilaku (ci) terhadap pembelian benih Jaya dan Bisi2:

- Potensi produksi yang relatif tinggi

- Daya adaptasi yang baik terhadap cuaca

- Harga tidak memberatkan secara keuangan bagi petani

- Memiliki perakaran dan batang yang baik dan kokoh

- Toleran terhadap penyakit bulai

- Memiliki umur panen relatif singkat

- Tanggap terhadap pemupukan

- Cocok untuk penanaman rapat / sela

Keyakinan normative (NBj) pada pembelian benih Jaya dan Bisi2:

- Anggota keluarga

- Orang lain

- Teman sesama petani

- Tenaga penjual

Motivasi (MCj) pada pembelian benih Jaya dan Bisi2:

- Anggota keluarga

- Orang lain

- Teman sesama petani

- Tenaga penjual
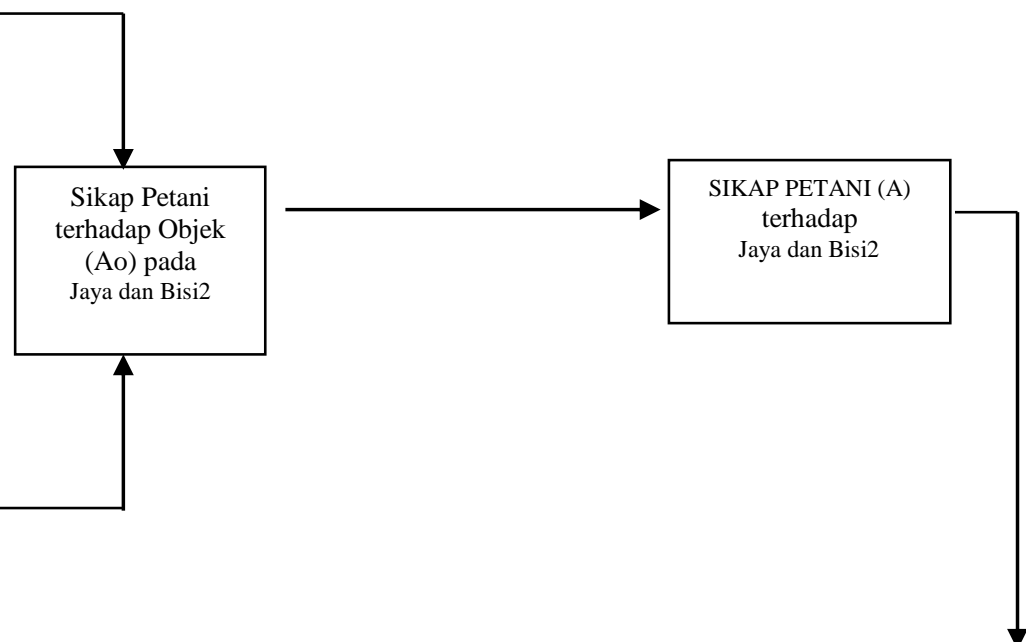

KAP PETANI DAN

PERILAKU PETANI

TERHADAP JAYA DAN BISI2 Perilaku (Abeh) pada pembelian Jaya dan Bisi2

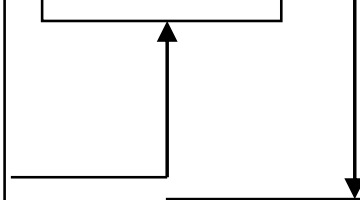

Maksud Perilaku Petani (BI) terhadap Pembelian Jaya dan Bisi2
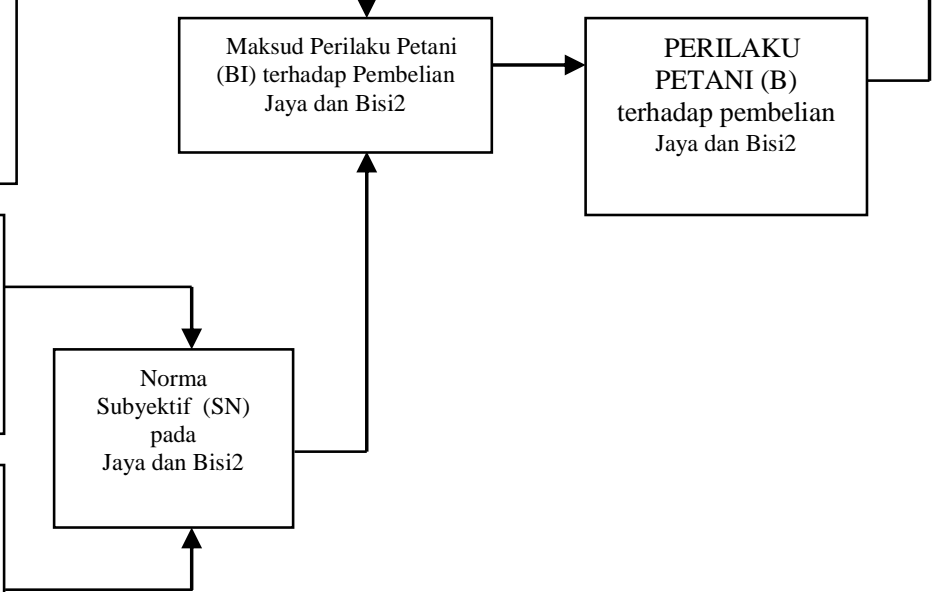

Gambar 2 Kerangka Pemikiran 
Kriteria ini dimasukkan karena dalam penelitian konsumen, pengalaman pembelian masa lalu suatu produk dapat menyebabkan pembelian kembali. Hal ini disebabkan karena konsumen telah memiliki pengetahuan dan pengalaman untuk menilai suatu merek atau membandingkan merek satu dengan merek lainnya (Betharia, 2001; Utama dan Purwanto, 2006

2. Responden adalah petani yang menggunakan produk secara langsung dan merasakan keuntungan dan kerugian produk.

Kriteria tersebut digunakan karena berkaitan dengan seluruh variabel terutama variabel kepercayaan pada merek atau objek, keterlibatan, dan pengambil keputusan pembelian (Lau dan Lee, 1999; Mc Quarrie dan Munson, 1992 dalam Utama dan Purwanto, 2006).

Setiap Responden mendapat dua perlakuan sekaligus yaitu sebagai responden untuk benih Jaya dan juga Bisi 2 karena penelitian ini bersifat within subject. Menurut Utama dan Purwanto (2006), metode within subject dapat dilakukan apabila konsumen memiliki pengetahuan dan pengalaman menggunakan kedua produk yang diuji. Pengambilan responden dilakukan dengan menggunakan metode simple random sampling. Menurut Singarimbun dan Effendi (1988), metode simple random sampling dapat diterapkan dengan persyaratan, yaitu populasi relatif homogen, tersedianya kerangka sampling dan keadaan populasi tidak terlalu tersebar. Teknik simple random sampling merupakan teknik penentuan responden di mana setiap populasi mempunyai kesempatan yang sama untuk dipilih menjadi responden. Populasi petani di Desa Sukasari dalam penelitian ini berjumlah 194 orang. Jumlah responden ditentukan dengan menggunakan rumus yaitu (Nazir, 1988) :

$$
\begin{aligned}
& \mathrm{n}=\mathrm{N} \cdot \mathrm{p}(1-\mathrm{p}) \\
& (\mathrm{N}-1) \mathrm{D}+\mathrm{p}(1-\mathrm{p}) \\
& \mathrm{N}=\text { Jumlah populasi } \\
& \mathrm{P} \quad=\quad \text { Proporsi }
\end{aligned}
$$

Dimana : $\mathrm{n} \quad=$ Jumlah responden

responden dari populasi

$$
\begin{array}{ll}
\mathrm{D} & =\mathrm{B}^{2} / 4 \\
\mathrm{~B} & =\text { Bound of error } 10
\end{array}
$$

$\%(0,10)$

Diketahui : $\quad \mathrm{N}=194$ orang

$$
\begin{aligned}
& \mathrm{P}= 0,5 \\
& \mathrm{D}=0,10^{2} / 4=0.0025 \\
& \mathrm{n}=194(0,5)(1-0,5) / \\
&(194-1) 0,0025+0,5(1-0,5) \\
&=48.5 /(0.4825+0.25) \\
&=66,21 \text { orang } \approx 66 \text { orang }
\end{aligned}
$$




\section{Metode Pengumpulan Data}

Pada penelitian ini ada beberapa metode pengumpulan data yang digunakan yaitu :

1. Data primer

Data primer diambil atau diperoleh dengan wawancara terstruktur terhadap petani pengguna Jaya dan Bisi 2 berdasarkan pertanyaan yang telah disiapkan dengan menggunakan kuisioner. Pertanyaan tersebut terdiri dari pertanyaan pendahuluan, identitas responden dan variabel keyakinan terhadap atribut dan tentang perilaku, variabel evaluasi terhadap atribut dan tentang perilaku, variabel keyakinan normative serta variabel motivasi yang diajukan berupa pertanyaan tertutup dan terbuka. Artinya jawaban responden terbatas pada alternatif-alternatif yang telah disediakan dan disertai alasan dari jawaban yang dipilih.

2. Data sekunder

Data sekunder diperoleh dari instansi atau lembaga yang berhubungan dengan penelitian, antara lain dari Badan Pengawasan dan Sertifikasi Benih Tanaman Pangan dan Hortikultura Bengkulu, Dinas Pertanian dan Tanaman Pangan Bengkulu Biro Pusat Statistik Propinsi Bengkulu, serta instansi terkait lainnya dan studi pustaka/referensi serta literatur yang berkaitan dengan penelitian.

\section{Metode Analisis Data}

\section{Metode Deskriptif}

Metode deskriptif berupa penjelasan atau pembahasan yang diperoleh selama penelitian dilaksanakan. Menurut Sugiyono (2002), analisis deskriptif digunakan untuk menjelaskan segala sesuatu mengenai data yang diperoleh dan disajikan dalam penelitian agar data-data tersebut menjadi lebih mudah dipahami.

\section{Metode Analisis Sikap Fishbein}

Teori Fishbein digunakan karena lebih mudah diaplikasikan dibandingkan dengan teori lain (Rosenberg), karena Fishbein menjelaskan pembentukan sikap sebagai tanggapan atas atribut-atribut. Model Fishbein memungkinkan para pemasar mendiagnosis kekuatan dan kelemahan merek produk mereka secara relatif dibandingkan dengan merek produk pesaing mereka dengan menetukan bagaimana konsumen mengevaluasi alternatif merek produk pada atribut-atribut penting.

\section{a. Analisis Sikap Petani terhadap Benih}

Untuk mengetahui bagaimana sikap terhadap benih jagung Jaya dan Bisi 2 maka data yang diperoleh dianalisis dengan menggunakan model multiatribut dari Fishbein. Model sikap ini memperlihatkan sikap terhadap obyek (Ao) bergantung pada probabilitas bahwa suatu obyek mempunyai atribut0atribut tertentu (bi), 
dan pada tingkat diinginkannya atributatribut itu (ei). Persamaan aljabar model multiatribut adalah sebagi berikut :

$$
\mathrm{A}_{\mathrm{o}}=\sum_{\mathrm{i}}^{\mathrm{n}}(\mathrm{bi})(\mathrm{ei})
$$

Dimana :

$\mathrm{A}_{\mathrm{o}}=$ Sikap terhadap benih

$\mathrm{Bi}=$ Tingkat keyakinan konsumen bahwa benih memiliki atribut ke-i

ei = Evaluasi keyakinan konsumen bahwa benih memiliki atribut ke-i

$\mathrm{n}$ = jumlah kriteria atribut yang relevan dengan benih

Hipotesis secara matematis adalah sebagai berikuit :

Ho : Ao $=0$; maka nilai total sikap petani tetap / negatif

Ha : Ao > 0 ; maka nilai total sikap petani positif

\section{b. Analisis Perilaku Petani}

Perilaku petani dianalisis dengan model reasoned action dari Fishbein (Sutisna, 2001). Sikap yang diukur adalah sikap terhadap perilaku seperti yang disebutkan oleh Schiffman dan Kanuk dalam Simamora (2002) bahwa sikap terhadap perilaku lebih tepat digunakan untuk memprediksi maksud perilaku petani berdasarkan sikap. Persamaan aljabar model reasoned action adalah :

$$
\mathrm{A}_{\text {beh }}=\sum_{\mathrm{i}}^{\mathrm{n}}(\mathrm{bi})(\mathrm{ei})
$$

Dimana :

$\mathrm{A}_{\text {beh }}=$ Sikap terhadap perilaku pembelian benih

$\mathrm{Bi}=$ Tingkat keyakinan konsumen bahwa perilaku pembelian memiliki atribut ke-i

$\mathrm{Ei}=$ Evaluasi keyakinan konsumen bahwa perilaku pembelian memiliki atribut ke-i

$\mathrm{n}=$ Jumlah kriteria atribut yang relevan

Nilai Sikap yang diperoleh melalui formula sikap terhadap perilaku digunakan untuk mengetahui perilaku petani yang diukur dengan model maksud perilaku (behavior intention). Maksud perilaku dibentuk oleh komponen sikap terhadap perilaku dan norma subjektif. Norma subjektif ditentukan dengan formula :

$$
\mathrm{SN}=\sum_{\mathrm{J}=1}^{\mathrm{m}}(\mathrm{NBj})(\mathrm{MCj})
$$

Dimana :

$\mathrm{SN}=$ Norma subjektif

$\mathrm{NBj}=$ Keyakinan normative individu

$\mathrm{MCj}=$ Motivasi konsumen

$\mathrm{M} \quad$ = Banyak atribut yang relevan

Dan untuk memperoleh konsistensi antara sikap dan perilaku, maka digunakan Model Maksud Perilaku Fishbein dengan formula : 
$\mathrm{B} \approx \mathrm{BI}=\mathrm{w}_{1}\left(\mathrm{~A}_{\text {beh }}\right)+\mathrm{w}_{2}(\mathrm{SN})$

Dimana :

$\mathrm{B}=$ Perilaku Petani

BI = Maksud perilaku (Behavior Intention)

A beh = Sikap terhadap perilaku pembelian benih

SN = Norma subyektif

$\mathrm{w} 1, \mathrm{w} 2$ = Bobot yang digunakan secara empiris dan menggambarkan pengaruh relatif dari variabel (jika faktor lain tidak dihitung, maka nilai maksud perilaku ekuivalen dengan perilaku). Menurut Bitta (1993) dalam Umar (2003), nilai $\mathrm{w}_{1}=0,6$ dan nilai $\mathrm{w}_{2}=0,4$

Hipotesis secara matematis adalah sebagai berikuit :

Ho : $\mathrm{B}=0$; maka perilaku petani tetap atau negatif

$\mathrm{Ha}$ : $\mathrm{B}>0$; maka perilaku petani baik atau positif

\section{c. Kriteria Sikap dan Perilaku petani}

Nilai sikap terhadap objek (Ao), sikap terhadap perilaku (Abeh), dan perilaku konsumen (B) yang diperoleh kriteria ke dalam lima kategori yaitu : positif, sangat positif, biasa saja, negatif dan sangat negatif. Untuk norma subjektif (SN) dengan kriteria sangat menganjurkan, menganjurkan, biasa saja, melarang dan sangat melarang. Rumus penentuan kriteria adalah sebagai berikut :

$$
\mathrm{RK}=\frac{\mathrm{m}-\mathrm{n}}{\mathrm{b}}
$$

Dimana :

$\mathrm{RK}=$ Rentang kelas

$\mathrm{m}=$ Jumlah skor tertinggi yang mungkin

$\mathrm{n}=$ Jumlah skor terendah yang mungkin

b = Jumlah kategori

\section{d. Uji Beda}

Untuk melihat apakah secara statistik sikap petani terhadap Jaya dan Bisi 2 sebagai benih dominan digunakan petani sama atau terdapat perbedaan yang signifikan. Uji beda yang digunakan adalah uji hipotesis komparatif dua mean dari dua sampel dengan Z-test dimana sampel yang diambil dari populasi normal atau jumlah sampel besar $\left(\mathrm{n}_{1} ; \mathrm{n}_{2}>30\right)$ (Walpole, 1995 dalam Djarwanto, 2001). Rumus :

$$
Z_{\text {hitung }}=\frac{X_{1}-X_{2}}{\sqrt{\frac{\mathrm{s}_{1}^{2}+s_{2}^{2}}{n}-\frac{n}{n}}}
$$

Dimana : $X_{1}, X_{2}=$ Nilai rata-rata sikap petani

$$
\begin{aligned}
& \mathrm{S}_{1}, \mathrm{~S}_{2}=\text { Varian Sikap petani } \\
& \mathrm{n}_{1}, \mathrm{n}_{2}=\text { Jumlah petani }
\end{aligned}
$$

HASIL DAN PEMBAHASAN

Frekuensi Menggunakan Jaya dan Bisi 2 Analisis Sikap Petani Terhadap Produk Jaya dan Bisi 2 
Pengukuran sikap petani dalam penelitian ini merupakan aplikasi dari model multiatribut dari Fishbein. Model Fishbein memperlihatkan bahwa sikap terbentuk dari tanggapan berbagai atribut dari produk yang ditawarkan. Lebih lanjut, model multiatribut dari Fishbein menjelaskan sikap terhadap suatu objek (Ao) bergantung pada probabilitas bahwa suatu objek mempunyai atribut-atribut tertentu (bi), dan pada tingkat diinginkannya atribut-atribut itu (ei) (Sutisna, 2001). Berdasarkan pengukuran diperoleh hasil sikap petani terhadap nilai/skor Fishbein, skor sikap total petani terhadap benih Jaya adalah sebesar 6,83 atau termasuk kategori biasa saja sedangkan sikap terhadap benih Bisi2 adalah sebesar 5,79 dengan kategori biasa saja. Hasil pengukuran menunjukkan bahwa petani lebih menyukai produk benih Jaya dibandingkan Bisi2.

Dekalb C7 lebih tinggi dari sikap petani terhadap Pioneer P12. Untuk atribut desain kemasan $\left(\mathrm{A}_{1}\right)$, atribut ukuran kemasan $\left(\mathrm{A}_{2}\right)$ dan atribut bentuk benih $\left(\mathrm{A}_{3 \mathrm{~b}}\right)$ diperoleh bahwa sikap petani terhadap ketiga atribut tersebut pada Bisi2 lebih tinggi dibanding Jaya . Dilihat dari Tabel sikap petani terhadap atribut-atribut Jaya dan Bisi 2 memiliki interpretasi relatif sama kecuali pada atribut ukuran kemasan $\left(\mathrm{A}_{2}\right)$, atribut harga yang terjangkau $\left(\mathrm{A}_{4}\right)$ serta atribut reputasi $\operatorname{merek}\left(\mathrm{A}_{8}\right)$.

Memperlihatkan sikap petani terhadap atribut warna benih $\left(\mathrm{A}_{3}\right)$, atribut harga yang terjangkau $\left(\mathrm{A}_{4}\right)$, atribut kualitas benih $\left(\mathrm{A}_{5}\right)$, atribut promosi $\left(\mathrm{A}_{6}\right)$, atribut kemudahan mendapatkan produk $\left(\mathrm{A}_{7}\right)$ dan atribut reputasi merek $\left(\mathrm{A}_{8}\right)$ pada

\section{Analisis Perilaku Petani Terhadap Benih} Jaya dan Bisi 2

$$
\text { Model-model sikap yang }
$$
berkembang akan mempunyai relevansi dalam pemasaran jika model tersebut mampu memprediksi perilaku konsumen. Model reasoned action atau behavioral intentions merupakan modifikasi pengukuran sikap dari Fishbein yang melihat perilaku konsumen berdasarkan sikap. Model ini menjelaskan bahwa perilaku petani dalam penelitian dipengaruhi oleh dua komponen utama yaitu komponen sikap terhadap perilaku pembelian (Abeh) sebagai elemen internal individu dan norma subjektif (SN) sebagai pengaruh dari lingkungan.

\section{Sikap Petani Terhadap Pembelian Benih}

\section{Jaya dan Bisi 2}

Dari hasil pengukuran sikap petani terhadap perilaku pembelian benih jagung Jaya dan Bisi 2 didapat nilai / skor sikap total petani terhadap benih Jaya adalah sebesar 7,35 dengan kategori positif 
sedangkan sikap terhadap pembelian benih Bisi2 adalah sebesar 7,12 dengan kategori positif. Hasil pengukuran menunjukkan bahwa sikap total terhadap perilaku pembelian Jaya dan Bisi 2 memiliki nilai relatif sama.

Tabel 2. Distribusi Petani Menurut Frekuensi Menggunakan Benih

\begin{tabular}{cccccc}
\hline No & Frekuensi Menggunakan (kali) & Jaya (\%) & Rata-rata & Bisi2 (\%) & Rata-rata \\
\hline 1 & Rendah $(2-8)$ & 71,21 & & 69,70 & \\
2 & Sedang $(8-14)$ & 25,76 & 6,64 & 30,30 & 6,64 \\
3 & Tinggi $(>14)$ & 3,03 & & 0,00 & \\
\hline & Jumlah & $\mathbf{1 0 0 , 0 0}$ & & $\mathbf{1 0 0 , 0 0}$ & \\
\hline
\end{tabular}

Tabel 3. Nilai Rata-rata Sikap Petani Terhadap Atribut Benih Jaya dan Bisi 2

\begin{tabular}{|c|c|c|c|c|c|c|c|c|}
\hline \multirow{3}{*}{ No } & \multirow{3}{*}{ Atribut } & \multirow{3}{*}{$\mathrm{Ei}$} & \multicolumn{6}{|c|}{ Sikap Terhadap Produk } \\
\hline & & & \multicolumn{3}{|c|}{ Jaya } & \multicolumn{3}{|c|}{ Bisi2 } \\
\hline & & & $\mathrm{b}$ & $\mathrm{Ai}=$ ei.bi & Interpretasi & $\mathrm{b}$ & $\mathrm{Ai}=$ ei.bi & Interpretasi \\
\hline 1 & Desain kemasan & 0,89 & 0,56 & 0,73 & Biasa saja & 0,83 & 0,74 & Biasa saja \\
\hline 2 & Ukuran kemasan & 1,12 & 0,67 & 0,79 & Biasa saja & 0,83 & 0,91 & Positif \\
\hline $3 a$ & Warna benih & 0,58 & 0,58 & 0,55 & Biasa saja & 0,52 & 0,42 & Biasa saja \\
\hline $3 b$ & Bentuk benih & 1,08 & 0,7 & 0,91 & Positif & 0,79 & 1,05 & Positif \\
\hline 4 & Harga yang terjangkau & 1,61 & 0,55 & 1,08 & Positif & 0,02 & 0,03 & Biasa saja \\
\hline 5 & Kualitas benih & 1,38 & 0,52 & 0,8 & Biasa saja & 0,52 & 0,77 & Biasa saja \\
\hline 6 & Promosi & 0,33 & 0,23 & 0,41 & Biasa saja & 0,33 & 0,33 & Biasa saja \\
\hline 7 & $\begin{array}{l}\text { Kemudahanmendapatkan } \\
\text { produk }\end{array}$ & 1,12 & 0,47 & 0,55 & Biasa saja & 0,46 & 0,48 & Biasa saja \\
\hline 8 & Reputasi merek & 1,03 & 0,88 & 1,03 & Positif & 0,77 & 0,79 & Biasa saja \\
\hline & Sikap total terhadap $\mathrm{Ob}$ & k (Ao) & & 6,83 & Biasa saja & & 5,79 & Biasa saja \\
\hline
\end{tabular}


Tabel 4. Nilai Rata-rata Sikap Petani Terhadap Pembelian Benih Jaya dan Bisi 2

\begin{tabular}{|c|c|c|c|c|c|c|c|c|}
\hline \multirow{3}{*}{ No } & \multirow{3}{*}{ Atribut } & \multirow{3}{*}{ ei } & \multicolumn{6}{|c|}{ Sikap Terhadap Pembelian } \\
\hline & & & \multicolumn{3}{|c|}{ Jaya } & \multicolumn{3}{|c|}{ Bisi2 } \\
\hline & & & $\mathrm{b}$ & $\mathrm{Ai}=$ ei.bi & Interprtsi & $\mathrm{b}$ & $\mathrm{Ai}=$ ei.bi & Intrprtsi \\
\hline 1 & Produktivitas yang tinggi & 1,36 & 0,71 & 1,09 & Positif & 1,01 & 1,62 & Positif \\
\hline 2 & Daya adaptasi yang baik & 1,14 & 0,82 & 1,02 & Positif & 0,62 & 0,88 & Positif \\
\hline 3 & Harga tidak memberatkan keuangan & 1,03 & 0,53 & 0,58 & Biasa saja & 0,08 & 0,14 & Biasa saja \\
\hline 4 & Perakaran dan batang kokoh & 1,24 & 0,95 & 1,36 & Positif & 0,81 & 1,17 & Positif \\
\hline 5 & Toleran terhadap bulai & 1,23 & 0,5 & 0,77 & Biasa saja & 0,69 & 0,97 & Positif \\
\hline 6 & Umur panen relatif singkat & 0,98 & 0,61 & 0,76 & Biasa saja & 0,67 & 0,88 & Positif \\
\hline 7 & Tanggap terhadap pemupukan & 1,09 & 0,67 & 0,8 & Biasa saja & 0,65 & 0,8 & Biasa saja \\
\hline 8 & Cocok untuk penanaman rapat/sela & 0,85 & 0,71 & 0,97 & Positif & 0,42 & 0,67 & Biasa saja \\
\hline \multicolumn{4}{|c|}{ Sikap total terhadap Objek (Ao) } & 6,83 & Biasa saja & & 5,79 & Biasa saja \\
\hline
\end{tabular}

Tabel 5. Peringkat Nilai Kepentingan Terhadap Atribut Dan Persentase Sikap Terhadap Atribut Dari Sikap Total Terhadap Objek.

\begin{tabular}{|c|c|c|c|c|c|c|c|c|}
\hline \multirow{3}{*}{ No } & \multirow{3}{*}{ Atribut } & \multirow{3}{*}{ ei } & \multirow{3}{*}{ Rank } & \multirow{3}{*}{$\%$} & \multicolumn{4}{|c|}{ Sikap Terhadap Pembelian } \\
\hline & & & & & \multicolumn{2}{|c|}{ Jaya } & \multicolumn{2}{|c|}{ Bisi2 } \\
\hline & & & & & $\mathrm{Ai}=$ ei.bi & $\%$ & $\mathrm{Ai}=$ ei.bi & $\%$ \\
\hline 1 & Produktivitas yang tinggi & 1,36 & 1 & 15,25 & 1,09 & 14,83 & 1,62 & 22,75 \\
\hline 2 & Daya adaptasi yang baik & 1,14 & 4 & 12,78 & 1,02 & 13,88 & 0,88 & 12,36 \\
\hline 3 & Harga tidak memberatkan keuangan & 1,03 & 6 & 11,55 & 0,58 & 7,891 & 0,14 & 1,97 \\
\hline 4 & Perakaran dan batang kokoh & 1,24 & 2 & 13,90 & 1,36 & 18,5 & 1,17 & 16,43 \\
\hline 5 & Toleran terhadap bulai & 1,23 & 3 & 13,79 & 0,77 & 10,48 & 0,97 & 13,62 \\
\hline 6 & Umur panen relatif singkat & 0,98 & 7 & 10,99 & 0,76 & 10,34 & 0,88 & 12,36 \\
\hline 7 & Tanggap terhadap pemupukan & 1,09 & 5 & 12,22 & 0,8 & 10,88 & 0,8 & 11,24 \\
\hline 8 & Cocok untuk penanaman rapat/sela & 0,85 & 8 & 9,53 & 0,97 & 13,2 & 0,67 & 9,41 \\
\hline \multicolumn{2}{|r|}{ Sikap total terhadap Pembelian (Abeh) } & 8,92 & & 100,00 & 7,35 & 100,00 & 7,12 & 100,14 \\
\hline
\end{tabular}

Pada Tabel 4 diperlihatkan bahwa atribut atau akibat pembelian yang dianggap penting dari kedua produk benih jagung adalah produktivitas yang tinggi $\left(\mathrm{A}_{1}\right)$, daya adaptasi yang baik $\left(\mathrm{A}_{2}\right)$, perakaran dan batang kokoh $\left(\mathrm{A}_{4}\right)$. Sikap petani terhadap perilaku pembelian pada atribut toleran terhadap bulai ( $\left.\mathrm{A}_{5}\right)$ dan umur panen relatif singkat $\left(\mathrm{A}_{6}\right)$ Jaya berdasarkan nilai rata-rata tertimbang diinterpretasikan biasa saja lebih rendah dibanding sikap petani terhadap perilaku pembelian pada atribut toleran terhadap bulai dan umur panen relatif singkat $\left(\mathrm{A}_{6}\right)$ 
Bisi2 yang diinterpretasikan positif. Di sisi lain, sikap petani terhadap perilaku pembelian pada atribut cocok untuk penanaman rapat atau sela $\left(\mathrm{A}_{8}\right)$ Jaya berdasarkan nilai rata-rata tertimbang diinterpretasikan postif lebih tinggi dibanding sikap petani terhadap perilaku pembelian pada atribut tersebut Bisi2 diinterpretasikan biasa saja.

\section{Tingkat Kepentingan Atribut}

Produk sebetulnya dapat dipandang sebagai sekumpulan atribut. Pada saat mengambil keputusan mengenai merek apa yang dipilih, yang dipertimbangkan konsumen adalah atribut produk. Konsumen akan mengidentifikasi atribut-atribut atau karakteristik yang dimiliki oleh objek yang akan dievaluasi. Nilai evaluasi konsumen terhadap setiap atribut produk jika diurutkan dapat memberikan informasi mengenai tingkat kepentingan atribut tersebut. Menurut Sumarwan (2003), evaluasi adalah evaluasi baik atau buruknya suatu atribut (evaluation of the goodness or badness of attribute atau importance weighter), yaitu menggambarkan pentingnya suatu atribut bagi konsumen. Dengan kata lain, semakin tinggi nilai evaluasi konsumen terhadap atribut maka semakin penting atribut tersebut untuk dipertimbangkan oleh konsumen.

\section{Norma Subjektif Petani}

Nilai norma subjektif petani (SN) merupakan penilaian petani terhadap pengaruh eksternal yang akan mempengaruhi perilaku pengadopsian (pembelian) petani. Nilai norma subjektif diketahui dari perkalian antara nilai ratarata tertimbang variabel keyakinan normative $(\mathrm{NBj})$ dengan nilai rata-rata tertimbang variabel kenyataan yang memotivasi petani untuk melakukan pembelian (MCj).

\section{Perilaku Petani Terhadap Benih Jaya dan Bisi 2}

Menurut para ahli ekonomi, teori reasoned action dinilai lebih mampu memprediksi maksud dan perilaku pembelian konsumen terhadap suatu produk.

\section{Uji Beda Sikap Petani Terhadap Benih Jagung}

Sikap yang dimiliki oleh petani terhadap suatu objek bervariasi pada sekitar kontinum sikap mulai dari yang paling negatif sampai yang paling positif. Sikap yang lebih positif dan lebih kuat akan cenderung mudah untuk dipanggil kembali dari memori, sehingga akan lebih memungkinkan untuk mempengaruhi perilaku. Dengan kata lain, sikap yang lebih tinggi terhadap suatu merek benih 
jagung akan memungkinkan petani untuk membeli benih tersebut disbanding merek lain yang dinilai memiliki sikap yang lebih rendah. Hasil pengukuran sikap petani terhadap produk Jaya dan Bisi 2 berbeda $(6,83$ dan 5,79) dengan kategori masing-masing adalah biasa saja. Hal ini dapat diartikan bahwa petani akan lebih cenderung memilih Jaya dibanding Bisi2 dalam usahatani jagung di masa akan datang. Namun untuk mengatakan apakah sikap keduanya benar-benar berbeda atau berbeda signifikan maka diperlukan pembuktian statistik. Dalam penelitian ini digunakan uji hipotesis komparatif rata-rata dua sample dengan z-test dua arah (two tail test) pada taraf kepercayaan sebesar $95 \%$.

Tabel 6. Nilai Rata-rata Sikap Petani Terhadap Atribut Benih Jaya dan Bisi 2

\begin{tabular}{ccccccccccc}
\hline \multirow{2}{*}{ No } & \multirow{2}{*}{ Atribut } & \multicolumn{4}{c}{ Jaya } & \multicolumn{4}{c}{ Bisi2 } \\
\cline { 3 - 10 } & & NBj & MCj & SN & Interpretasi & NBj & MCj & SN & Interpretasi \\
\hline 1 & Anggota keluarga & 0,58 & 0,29 & 0,44 & Biasa saja & 0,52 & 0,33 & 0,48 & Biasa saja \\
2 & Teman sesama Petani & 0,61 & 0,35 & 0,44 & Biasa saja & 0,58 & 0,42 & 0,50 & Biasa saja \\
3 & Tenaga penjual & 0,36 & 0,05 & 0,08 & Biasa saja & 0,39 & 0,05 & $-0,08$ & Biasa saja \\
4 & Orang lain & 0,27 & $-0,05$ & $-0,18$ & Biasa saja & 0,27 & 0,02 & 0,21 & Biasa saja \\
\hline & \multicolumn{2}{c}{ Total Norma subjektif } & & $\mathbf{0 , 7 8}$ & Biasa saja & & & $\mathbf{1 , 1 1}$ & Biasa saja \\
\hline
\end{tabular}

Tabel 7. Nilai Perilaku Petani Terhadap Benih Jaya dan Bisi 2

\begin{tabular}{cccccccc}
\hline No & Benih Jagung & $\begin{array}{c}\text { Sikap Terhadap } \\
\text { Perilaku (Abeh) }\end{array}$ & Kategori & $\begin{array}{c}\text { Norma Subjektif } \\
(\text { SN })\end{array}$ & Kategori & $\begin{array}{c}\text { Perilaku } \\
\text { Petani (B) }\end{array}$ & Kategori \\
\hline 1 & Jaya & 7,35 & Positif & 0,78 & Biasa saja & 0,60 & Positif \\
2 & Bisi 2 & 7,12 & Positif & 1,11 & Biasa saja & 0,60 & Positif \\
\hline
\end{tabular}

Tabel 8. Hasil Uji Hipotesis Rata-rata Dua Sampel

\begin{tabular}{lcccc}
\hline \multicolumn{1}{c}{ Sampel } & $\begin{array}{c}\text { Nilai Rata-rata Sikap Thd } \\
\text { Objek (Ao) }\end{array}$ & Varian sikap & z-hitung & z-tabel \\
\hline Benih Jagung Jaya & 6.83 & 33.40 & $0.19(-0.19)$ & $1,96(-1,96)$ \\
Benih Jagung Bisi2 & 5.79 & 30.60 & \\
\hline
\end{tabular}




\section{KESIMPULAN}

Berdasarkan hasil penelitian diperoleh kesimpulan bahwa sikap petani terhadap benih jagung Jaya dan benih jagung Bisi adalah biasa saja, artinya petani merasa tidak ada masalah terhadap atribut-atribut benih jagung secara umum pada kedua jenis benih tersebut dari sisi atribut-atribut produk yang ditawarkan. Perilaku petani terhadap benih jagung Jaya dan benih jagung Bisi2 adalah positif. Hal ini sangat memungkinkan petani untuk melakukan pembelian kembali (berulang) kedua merek benih jagung tersebut. Sikap petani terhadap produk benih jagung Jaya dan Bisi2 adalah sama atau tidak berbeda nyata.

\section{DAFTAR PUSTAKA}

Anonim. 2007. Urgensi Pengembangan Jagung di Indonesia. PSDALLP3ES @ Http://google.com. Jakarta.

Darmowiyono, Subagyono. 1999. Perjalanan Panjang Membangun Sistem Perbenihan Tanaman Pangan dan Hortikultura. Penerbit Pustaka Sinar Harapan. Jakarta.

Dinas Pertanian dan Tanaman Pangan Propinsi Bengkulu. 2005. Statistik Tanaman Pangan Propinsi Bengkulu. Dinas Pertanian Dan Tanaman Pangan Bengkulu. Bengkulu.

Djarwanto, PS. 2001. Mengenal Beberapa Uji Statistik Dalam Penelitian. Penerbit Liberty. Yogyakarta.

Hendrayana, dkk.2005. Stabilitas Jagung Hibrida pada beberapa lingkungan berbeda. Jurnal Agrosains Volume 18 Nomor 3:299-304.
Ika, Rachjatun Sastrahidayat. 1993. Ilmu Penyakit Tumbuhan. Surabaya. Usaha Nasional.

Kotler, Philip dan Susanto, AB. 2000. Manajemen Pemasaran di Indonesia. Jakarta. Penerbit Salemba Empat.

Mowen, John C. 1995. Consumer Behavior. Engelwood. Prantice Hall.

Mubyarto. 1989. Pengantar Ekonomi Pertanian. LP3ES. Jakarta.

Nazir, M. 1988. Metode Penelitian. Ghalia Indonesia. Jakarta.

Rukmana, R. 1997. Usahatani Jagung. Kanisius. Yogyakarta.

Sarwanto, T Adi dan Yustina Erna Widiastuti. 2004. Meningkatkan Produksi Jagung di Lahan Kering, Sawah dan Pasang Surut. Penebar Swadaya. Jakarta.

Setiadi, Nugroho J. 2003. Perilaku Konsumen. Prenada Medi. Jakarta

Simamora, B. 2002. Panduan Riset Perilaku Konsumen. Gramedia Pustaka Utama. Jakarta.

Sugiyono. 2002. Metode Penelitian administrasi. Bansung. Penerbit Alfabeta

Sumarwan, Ujang. 2003. Perilaku Konsumen, Teori dan Penerapannya dalam Pemasaran. Jakarta. Penerbit Ghalia Indonesia.

Surjadi, dkk. 2002. Pengaruh Iklan Terhadap Perilaku Pembelian Konsumen Teh Dalam Keluarga. Bandung. Jurnal Agro Ekonomi Volume 2 Nomor 2 : 92-107.

Sutisna. 2001. Perilaku Konsumen dan Komunikasi Pemasaran. Badung. PT Remaja Rosda Karya.

Sutopo, Lita. 1985. Teknologi Benih. Jakarta. Penerbit Rajawali.

Swasta, Basu dan Irawan.1998. Manajemen Pemasaran Modern. Penerbit Liberty. Yogykarta.

Soekartawi. 1996. Pembangunan Pertanian Mengentaskan Kemiskinan. Jakarta. UI Press.

Thirtawati. 2004. Analisis Perilaku dan Konsistensi Petani dalam Penggunaan Pestisida Ramah 
Lingkungan (Kasus Petani Sayuran di Desa Sindangjaya Kecamatan Pacet Kabupaten Cianjur Jawa Barat). Jurnal KPM Volume 1 Nomor $3: 150-158$.

Tim Penyusun RS Kamus Pertanian Umum. Kamus Pertanian Umum. PT Penebar Swadaya. Jakarta.

Umar, H. 1998. Metode Penelitian untuk Skripsi dan Tesis Bisnis. Rajawali Pers. Jakarta
2003. Riset Pemasaran dan Perilaku Konsumen. PT. Gramedia Pustaka Utama. Jakarta.

Utama, Diosi Budi dan Purwanto, B.M.. 2006. Pengujian Antecedents Kepercayaan Konsumen pada Merek dan Pengaruhnya terhadap Loyalitas - Peran Involvement Sebagai Variabel Moderator. Jurnal Sosiosains Volume 19 Nomor 4 : 501-522. 